\title{
DYNAMOTHERMAL METAMORPHIC SEBAGAI PROVENANCE ENDAPAN SEDIMEN DAERAH ALIRAN SUNGAI KALIGARANG SEMARANG BERDASARKAN ANALISIS MINERAL BERAT
}

\author{
FX Anjar Tri Laksono*, Asmoro Widagdo, Sachrul Iswahyudi \\ Jurusan Teknik Geologi, Fakultas Teknik, Universitas Jenderal Soedirman \\ *Penulis Koresponden : anjar.trilaksono@unsoed.ac.id
}

\begin{abstract}
Abstrak. Daerah aliran Sungai Kaligarang Semarang yang mengalir dari selatan Semarang hingga bermuara di Semarang utara memiliki struktur sesar aktif dan sedimentasi dari enam formasi batuan yang berbeda yaitu Formasi Kerek, Kalibeng, Kaligetas, Damar, batuan gunungapi Kaligesik, dan aluvium. Kajian ini akan membahas provenance endapan sedimen daerah aliran Sungai Kaligarang yang terkait dengan tectonic setting Semarang. Hasil kajian provenance ini dapat digunakan untuk korelasi batuan dan interpretasi mekanisme pengendapan sedimen di Sungai Kaligarang. Metode dilakukan dengan mengumpulkan sampel sedimen dari Sungai Kaligarang yang kemudian dianalisis menggunakan mikroskop binokuler untuk mengidentifikasi jenis-jenis mineral berat. Jumlah mineral berat dihitung dan kemudian ditampilkan pada histogram untuk mengetahui perbandingan antara frekuensi mineral berat daerah penelitian dengan klasifikasi Mc Lane. Hasil analisis mineral berat menunjukkan bahwa Sungai Kaligarang didominasi mineral berat berupa ilmenit, magnetit, silimanit, muskovit, zirkon, andalusit, garnet, dan turmalin. Provenance mineral berat tersebut adalah dynamothermal metamorphic yang terbentuk pada metamorfisme tingkat tinggi dan dipengaruhi oleh temperatur dan tekanan tinggi. Kesimpulan kajian ini adalah provenance berupa dynamothermal metamorphic sesuai dengan tectonic setting Semarang yang berada pada jalur orogenesa dan adanya pergerakan sesar mendatar dekstral yang kemudian mengalami reaktivasi pada zaman Kuarter menjadi sesar mendatar sinistral. Mineral ilmenit, magnetit, dan silimanit yang dominan pada endapan terkait dengan fasies metamorfisme greenschist yang terjadi pada tekanan dan suhu yang tinggi. Mineral-mineral tersebut terbentuk pada kulit bumi bagian dalam yang terkait dengan aktivitas orogenesa.
\end{abstract}

Kata Kunci: dynamothermal metamorphic, provenance, mineral berat, Kaligarang, Semarang

\begin{abstract}
The watershed of the Kaligarang Semarang River, which flows from the south of Semarang to its mouth in northern Semarang, has an active fault structure and sedimentation from five different rock formations, namely the Kerek Formation, Kalibeng, Kaligetas, Damar, Kaligesik, and alluvium. This study will reveal the provenance of the Kaligarang River watershed sediment deposits associated with the tectonic setting of Semarang. The results of this provenance study can be used for rock correlation and interpretation of sediment deposition mechanisms in the Kaligarang River. The method is carried out by collecting sediment samples from the Kaligarang River which are then analyzed using a binocular microscope to identify the types of heavy minerals. The amount of heavy minerals is calculated and then displayed on the histogram to determine the comparison between the frequency of heavy minerals in the study area with the Mc Lane classification. The results of the heavy mineral analysis show that the Kaligarang River is dominated by heavy minerals in the form of ilmenite, magnetite, sillimanite, muscovite, zirkon, andalusite, garnet, and turmalin. The heavy mineral provenance is dynamothermal metamorphic which is formed in the high level of metamorphism and is influenced by high temperature and pressure. The conclusion of this study is a provenance in the form of dynamothermal metamorphic according to the tectonic setting of Semarang which is on the orogenetic belt and the movement of the dextral horizontal fault which experiences reactivation in the Quaternary era into a sinistral horizontal fault. The dominant ilmenite, magnetite, and silimanite minerals in the sediment are related to the greenschist metamorphism facies that occurs at high pressure and temperature. These minerals are formed in the earth's inner crust associated with orogenetic activity.
\end{abstract}

Keywords: dynamothermal metamorphic, provenance, heavy mineral, Kaligarang, Semarang 


\section{PENDAHULUAN}

Wilayah Semarang selatan dan utara memiliki morfologi yang berbeda. Bagian selatan terdiri dari perbukitan terjal yang didominasi litologi breksi vulkanik dan batupasir gunungapi berumur Kuarter (Kusuma dkk., 2017; Poedjoprajitno dkk., 2008; Raharjo dan Yosi, 2017). Sementara itu, Semarang utara memiliki morfologi berupa dataran rendah yang tersusun oleh breksi dan endapan aluvial (Fathullah dkk., 2015). Stratigrafi Kota Semarang terdiri dari enam formasi batuan dari tua ke muda yaitu Formasi Kerek, Formasi Kaligetas, Formasi Kalibeng, Formasi Damar, Formasi Kaligesik, dan endapan aluvial (Gambar 1) (Agista dkk., 2014; Laksono dkk., 2020).

Tectonic setting Kota Semarang dimulai dari Zaman Tersier Awal yang ditandai adanya intrusi basalt dan andesit sehingga terjadilah pengangkatan membentuk suatu tinggian (Fauzih dkk., 2019). Selain itu tenaga eksogen berupa erosi batuan pun terjadi. Produk dari adanya peristiwa erosi ini adalah terbentuknya endapan turbidit Formasi Kerek yang kemudian terendapkan pula Formasi Kalibeng di lingkungan pengendapan laut dalam (Rahayu dkk., 2016). Setelah itu terjadi pengendapan Formasi Damar pada lingkungan transisi hingga zona batial (Lestari dkk., 2020; Santoso, 2016). Pada Kala Pliosen hingga Pleistosen terjadi reaktivasi struktur geologi yang telah terbentuk pada Zaman Tersier Awal. Reaktivasi ini membentuk lipatan tak tersungkup, sesar geser yang berarah timurlaut-baratdaya, sesar normal, dan sesar naik yang berarah barat-timur (Nurhandoko dkk., 2020).

Jalur sesar aktif di Kota Semarang merupakan hasil dari tekanan kompresi yang berarah utaraselatan. Jalur sesar ini melewati Sungai Kaligarang dengan arah tegasan utama $(\sigma 1) \mathrm{N} 244^{\circ} \mathrm{E} / 5^{\circ}$, tegasan menengah $(\sigma 2) \mathrm{N} 347^{\circ} \mathrm{E} / 70^{\circ}$, dan tegasan yang paling

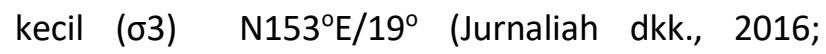
Purasongka dkk., 2015). Kenampakan sesar di Sungai Kaligarang ditandai adanya gawir sesar, terangkatnya teras sungai, gerakan tanah rayapan, dan rekahan batuan yang memotong Formasi Damar (Azeriansyah dkk., 2017; Laksono dkk., 2020). Jejak deretan pointbar dan perubahan pola aliran merupakan indikasi adanya sesar geser (Ghinassi dkk., 2019) .

Daerah aliran Sungai Kaligarang dari bagian hulu hingga ke hilir melewati batuan gunungapi Kaligesik, Formasi Kaligetas, Kerek, Kalibeng, Damar, dan endapan aluvium (Kusuma dkk., 2017). Batuan gunungapi Kaligesik terdiri dari lava basalt dengan komposisi mineral olivin, feldspar, dan augit. Formasi Kaligetas tersusun atas batulempung, breksi, lahar sisipan lava, dan batupasir sisipan tufan. Formasi Kerek terdiri atas napal, batupasir tufaan, konglomerat, batulempung, breksi vulkanik, dan batugamping. Formasi Kalibeng terdiri dari napal, batupasir tufaan, dan batugamping. Formasi Damar yang berumur Pleistosen tersusun oleh konglomerat, breksi vulkanik, dan batupasir tufaan (Fahrudin dkk., 2011; Jurnaliah dkk., 2016; Supriyadi dkk., 2020). Oleh karena itu, keenam formasi batuan tersebut kemungkinan akan menjadi sumber dari mineral berat yang diendapkan di Sungai Kaligarang bagian hilir yang bermuara ke laut. Sedangkan pada bagian tengah sungai kemungkinan akan ditemukan mineral berat yang bersumber dari batuan gunungapi Kaligesik, Formasi Kaligetas, Kerek, dan Kalibeng. Pada bagian hulu sungai batuan gunungapi Kaligesik diperkirakan akan menjadi provenance mineral berat (Hidayat dkk., 2011; Mispaki dkk., 2015).

Penelitian mengenai struktur geologi di Semarang telah dilakukan oleh para peneliti. Raharjo dan Yosi (2017) menyatakan bahwa zona sesar Kaligarang terbentuk sejak Zaman Tersier dan mengalami reaktivasi pada Pliosen-Pleistosen. Jalur zona sesar aktif Kaligarang yang membujur dari arah selatan ke utara Semarang diperkirakan berpengaruh besar terhadap metamorfisme di Semarang. Zona sesar Kaligarang (Gambar 1) ini kemungkinan akan menjadi sumber panas dan tekanan ketika metamorfisme. Poedjoprajitno dkk. (2008) mengatakan bahwa endapan Kuarter di Semarang terdiri dari Anggota Batupasir Formasi Damar dan endapan Cekungan Banjir. Akan tetapi studi mengenai provenance endapan sedimen di Sungai Kaligarang belum pernah dilakukan. Kompleksitas struktur geologi dan stratigrafi regional Semarang 


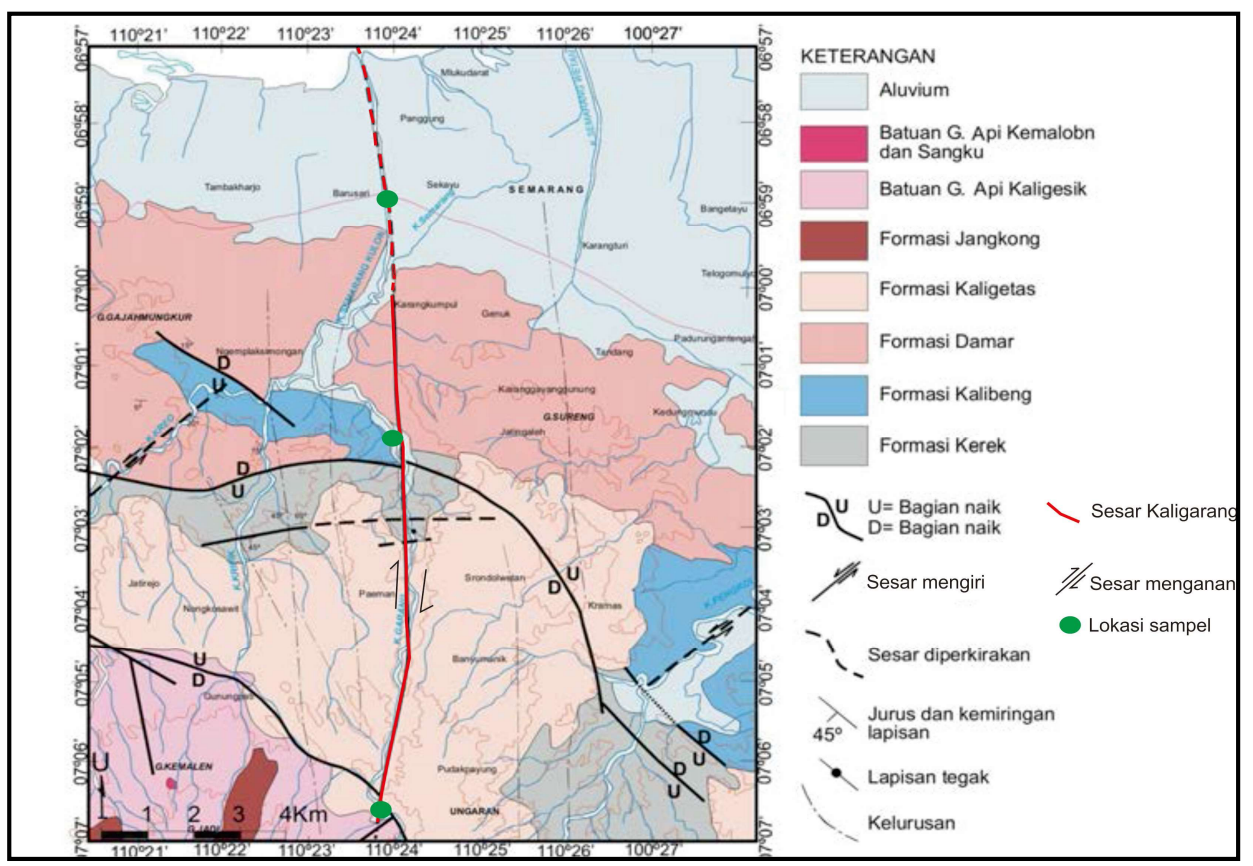

Gambar 1. Peta geologi regional Semarang tersusun oleh enam formasi batuan dari tua ke muda yaitu Formasi Kerek, Kalibeng, Kaligetas, Damar, Batuan gunung api Formasi Kaligesik, dan Aluvium. Pengambilan sampel berada di hulu Sungai Kaligarang (Ungaran), tengah sungai (Jatingaleh), dan bagian hilir Sungai Kaligarang (Sampangan)

(Poedjoprajitno dkk., 2008)

menjadi latar belakang pentingnya studi provenance endapan sedimen di Sungai Kaligarang. Tujuan dari penelitian ini adalah mengetahui provenance endapan sedimen daerah aliran Sungai Kaligarang dan kaitannya dengan tectonic setting Semarang. Sungai Kaligarang dipilih menjadi lokasi penelitian karena keberadaan bukti-bukti morfotektonik yang terlihat jelas. Adanya kajian provenance ini dapat digunakan sebagai langkah awal untuk merekonstruksi sejarah geologi Kota Semarang secara komprehensif.

\section{METODOLOGI}

Metode yang digunakan dalam kajian provenance endapan sedimen di Sungai Kaligarang adalah pengambilan sampel sedimen dan analisis mineral berat (Gambar 2). Sedimen dikumpulkan dari tiga bagian channel yang berbeda yaitu hulu, tengah, dan hilir sungai. Dalam pengambilan sampel penampang sungai dibagi menjadi tiga yaitu dua bagian tepi sungai dan satu bagian tengah. Sampel dimasukkan kedalam kantong sampel dan diberikan penomoran beserta keterangan lokasi pengambilan.

Analisis mineral berat dilakukan di laboratorium sedimentologi dengan memanfaatkan alat dan

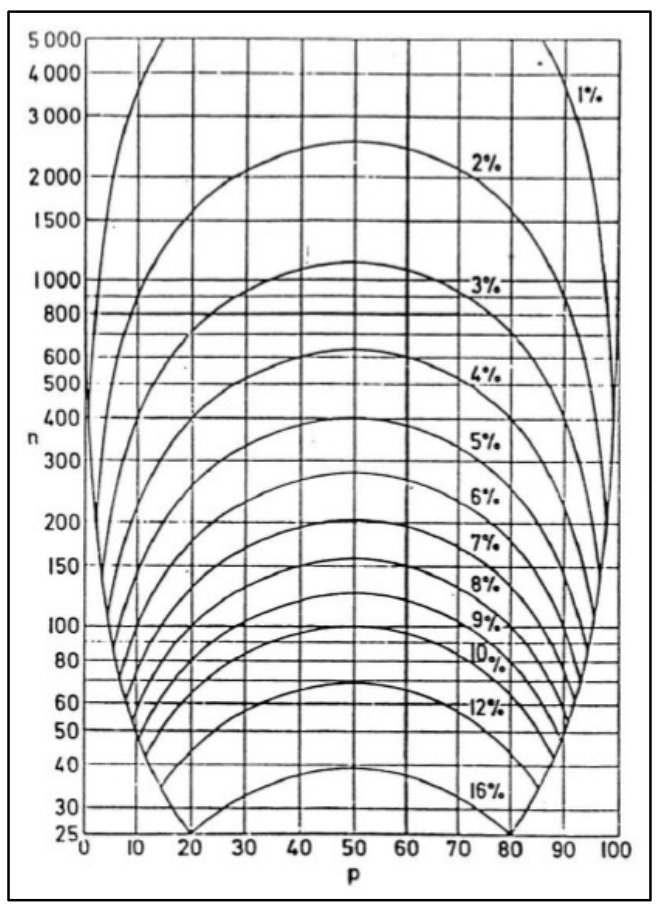

Gambar 2. Diagram Van der Plas yang digunakan untuk mencari nilai simpangan baku mineral berat. Simbol $n=$ jumlah total mineral yang dihitung, $p=$ persentase setiap mineral. Misalnya: $n=300, p=$ $25 \%$, maka simpangan bakunya adalah $5 \%$. Sehingga persentase mineral yang dihitung antara $20 \%-30 \%$. Dalam hal ini nilai $p+$ simpangan baku yang diambil, sehingga p terkoreksi 30\% (Rohendi dan Aryanto, 2016; Setyanto dan Surachman, 2017) 
bahan seperti separation funnel, tabung erlenmeyer, corong gelas, kertas saring, pengaduk gelas, timbangan, oven, mikroskop binokuler, jarum, olate, air, sampel sedimen, dan larutan bromoform. Langkah-langkah analisis mineral berat adalah sebagai berikut: sampel sedimen dibersihkan menggunakan air untuk menghilangkan partikelpartikel berukuran sangat halus dan pengotor. Setelah itu semua sampel sedimen dikeringkan dengan oven. Sampel yang telah kering disiapkan dalam lempeng preparat yang kemudian diamati melalui mikroskop binokuler. Dalam pengamatan mikroskopis mineral berat dapat diidentifikasi dan dipisahkan dengan mineral pengotor.

Setelah mineral berat terpisah, dilakukan identifikasi nama mineral. Setelah itu dilakukan perhitungan jumlah masing-masing jenis mineral berat pada tiap sampel. Langkah berikutnya adalah membuat tabel jumlah mineral berat menurut jenis serta lokasi pengambilan. Koreksi dilakukan dengan diagram Van der Plas (Gambar 2) (Rohendi dan Aryanto, 2016; Setyanto dan Surachman, 2017) sehingga diketahui nilai simpangan baku dan nilai terkoreksinya. Langkah terakhir adalah melakukan analisis dan interpretasi dengan membuat histogram dari hasil persentase dan frekuensi mineral berat dan dibandingkan dengan tabel provenance menurut $\mathrm{Mc}$ Lane (Tabel 1) (llegieuno dkk., 2020; Nádaskay dkk., 2019). Diagram alir penelitian provenance endapan
Sungai Kaligarang Semarang ditunjukkan dengan Gambar 3.

\section{HASIL DAN PEMBAHASAN}

Pengambilan sampel sedimen dilakukan di Sungai Kaligarang bagian hulu, tengah, dan hilir. Morfologi lokasi pengamatan adalah bentuk lahan fluvial (Gambar 4). Sungai pada lokasi pengamatan ini memiliki lebar rata-rata 30 meter. Sungai Kaligarang merupakan sungai stadia tua, hal tersebut dapat dibuktikan dengan lebar sungai yang besar sebagai indikasi bahwa erosi lateral lebih intensif dibandingkan erosi vertikal, selain itu arus sungai tergolong lambat sampai dengan sedang. Litologi yang terdapat di bagian hulu terdiri dari fragmenfragmen batuan gunung api dan metamorf. Di bagian tengah tersusun oleh fragmen batuan berukuran pasir halus hingga kasar, kerikil, dan kerakal. Sedangkan di bagian hilir didominasi endapan aluvial, sedimen pasir hingga lanau yang merupakan material eksitu. Ditinjau dari tata guna lahan daerah aliran sungai untuk bagian hulu merupakan daerah tangkapan air dan masih terdapat vegetasi alami yang lebat, akan tetapi di bagian tengah dan hilir telah digunakan sebagai banjir kanal yang daerah bantarannya terdapat pemukiman warga.

Analisis mineral berat pada bagian hulu sungai (Tabel 2) menunjukkan dominasi mineral magnetit yang mencakup $56,48 \%$ dari 100 gram sampel

Tabel 1. Asosiasi antara mineral berat dan provenance-nya menurut Mc Lane (llegieuno dkk., 2020; Nádaskay dkk., 2019)

\begin{tabular}{ll}
\hline \multicolumn{1}{c}{ Provenance } & \multicolumn{1}{c}{ Mineral Berat } \\
\hline Sedimen & Zircon bulat, turmalin, rutil, magnetit, titanit \\
Metamorfik tingkat rendah & Andalusit, staurolit, kondrodit \\
Metamorfik kontak & Korondum, topaz, turmalin, vesuvianit, zoisit, \\
& wollastonit, klorit, muskovit. \\
Metamorfik tingkat tinggi & Garnet, epidot, zoisit, staurolit, kyanit \\
Metamorfik dinamotermal & silimanit, andalusit, magnetit, titanit, zircon, biotit \\
Batuan beku asam & Monasit, titanit, zircon, turmalin, rutil, magnetit, \\
& apatit, muskovit \\
Batuan beku basa & Ilmenit, magnetit, anatase, brukit, diopsid, rutil, \\
Pegmatit & kromit, olivin \\
\hline
\end{tabular}




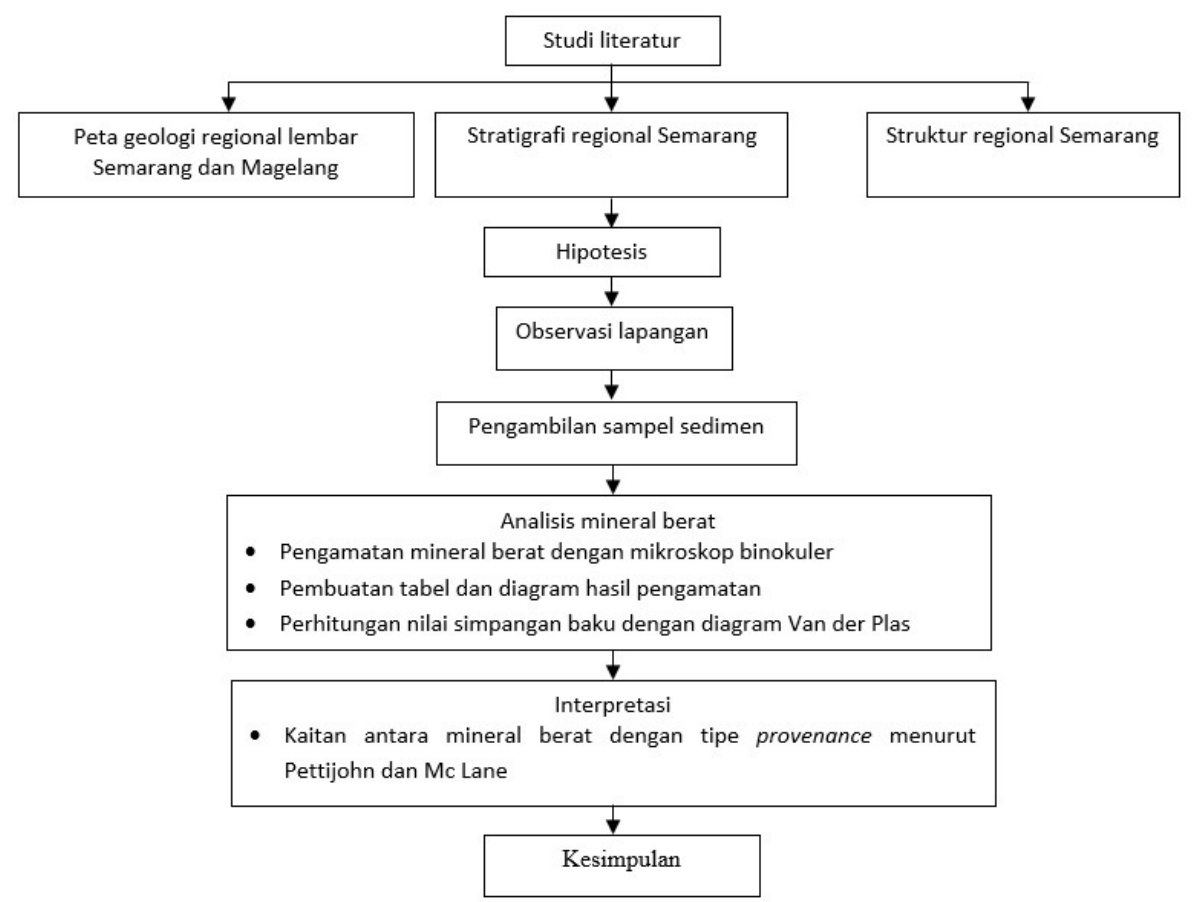

Gambar 1. Diagram alir penelitian dari mulai studi literatur hingga analisis mineral berat dan penarikan kesimpulan

Tabel 2. Data mineral berat di bagian hulu sungai menunjukkan mineral magnetit memiliki persentase terbanyak yaitu $56,48 \%$ dari 100 gram sampel sedimen yang dianalisis

\begin{tabular}{|c|c|c|c|c|c|c|}
\hline \multirow{2}{*}{ No. } & \multirow{2}{*}{ Mineral } & \multirow{2}{*}{ Frekuensi } & \multirow{2}{*}{ Persentase } & \multirow{2}{*}{ Deviasi } & \multicolumn{2}{|c|}{ Koreksi } \\
\hline & & & & & + & - \\
\hline 1 & Ilmenit & 5 & 1,90839695 & 2 & 7 & 3 \\
\hline 2 & Magnetit & 148 & 56,4885496 & 6 & 154 & 142 \\
\hline 3 & Zircon & 24 & 9,16030534 & 3 & 27 & 21 \\
\hline 4 & Hematit & 46 & 17,5572519 & 4 & 50 & 42 \\
\hline 5 & Olivin & 12 & 4,58015267 & 2 & 14 & 10 \\
\hline 6 & Garnet & 2 & 0,76335878 & 1 & 3 & 1 \\
\hline 7 & Andalusit & 25 & 9,54198473 & 4 & 29 & 21 \\
\hline Total & & 262 & 100 & 100 & 284 & 240 \\
\hline
\end{tabular}

sedimen yang dianalisis. Persentase terbesar berikutnya adalah hematit, andalusit, zirkon, olivin, dan ilmenit. Sementara itu, persentase garnet adalah yang terkecil hanya mencakup $0,76 \%$ dari total 100 gram berat sampel sedimen yang dianalisis. Persentase tersebut kemudian disajikan dalam bentuk diagram batang dan dilakukan koreksi $(+)$ maupun (-) (Gambar 4).

Mengacu pada Tabel 1 tentang kaitan antara asosiasi mineral berat dengan provenance menurut Mc Lane maka pada bagian hulu sungai provenancenya adalah metamorfik dinamotermal. Hal ini karena mineral berat seperti magnetit, hematit, andalusit, dan zirkon mendominasi komposisi sedimen. Mineral oksida besi magnetit dan hematit berasal dari Formasi batuan Gunungapi Kaligesik.
Pada bagian tengah sungai, mineral berat didominasi oleh magnetit diikuti ilmenit, silimanit, andalusit, pirit, olivin dan zirkon. Persentase magnetit mencapai $73,33 \%$, sedangkan olivin dan zirkon hanya $0,33 \%$ (Tabel 3). Persentase mineral berat kemudian dibuat diagram batang seperti pada Gambar 5. Berdasarkan klasifikasi Mc Lane maka provenance mineral berat pada bagian tengah sungai adalah metamorfik dinamotermal sama dengan bagian hulu Sungai Kaligarang. Akan tetapi pada bagian tengah sungai, frekuensi mineral ilmenit lebih banyak dibandingkan pada bagian hulu. Selain itu juga ditemukan mineral silimanit yang tidak dijumpai pada bagian hulu sungai. 


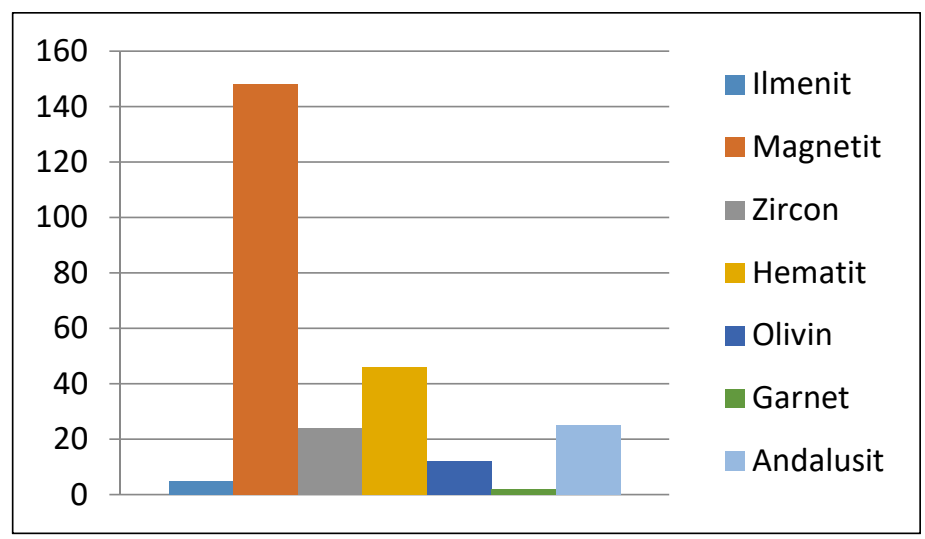

Gambar 4. Histogram nilai sebenarnya dari jumlah mineral berat. Frekuensi tertinggi secara berurutan adalah magnetit, hematit, andalusit, zircon, olivin, ilmenit, dan garnet

Tabel 3. Data mineral berat di bagian tengah Sungai Kaligarang didominasi magnetit, ilmenit, dan silimanit

\begin{tabular}{|c|c|c|c|c|c|c|}
\hline \multirow[b]{2}{*}{ No } & \multirow[b]{2}{*}{ Nama Mineral } & \multirow[b]{2}{*}{ Frekuensi } & \multirow[b]{2}{*}{ Persentase } & \multirow[b]{2}{*}{ Standar Deviasi } & \multicolumn{2}{|c|}{ Koreksi } \\
\hline & & & & & + & - \\
\hline 1 & Ilmenit & 38 & 12.67 & 4 & 16.67 & 8.67 \\
\hline 2 & Magnetit & 220 & 73.33 & 5 & 78.33 & 68.33 \\
\hline 3 & Andalusit & 3 & 1 & 2 & 3 & -1 \\
\hline 4 & Zircon & 1 & 0.33 & 2 & 2.33 & -1.67 \\
\hline 5 & Silimanit & 35 & 11.67 & 4 & 15.67 & 7.67 \\
\hline 6 & Pirit & 2 & 0.67 & 2 & 2.67 & -1.33 \\
\hline 7 & Olivin & 1 & 0.33 & 2 & 2.33 & -1.67 \\
\hline
\end{tabular}

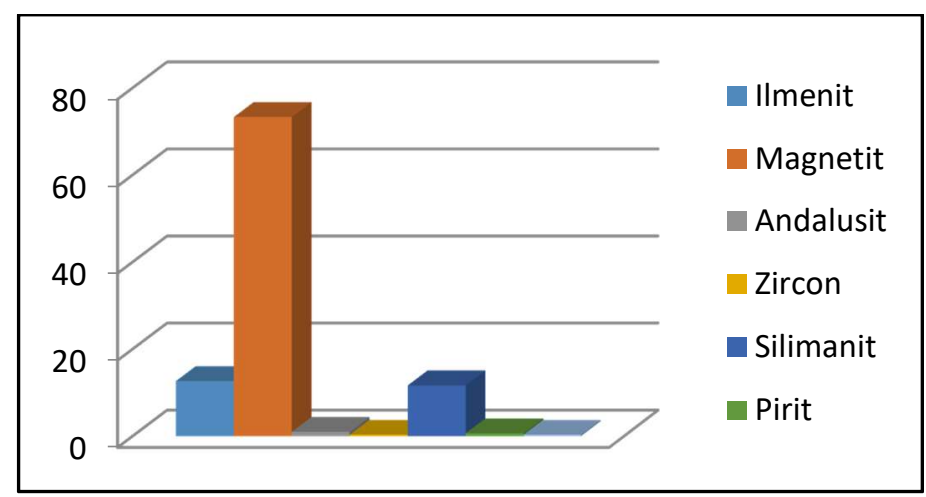

Gambar 5. Histogram jumlah mineral berat pada 100 gram sampel sedimen di bagian tengah Sungai Kaligarang

Keterdapatan mineral silimanit pada bagian tengah Sungai Kaligarang diinterpretasikan adanya metamorfisme regional dari batuan yang banyak mengandung aluminium dan silikat seperti lempung alumina. Oleh karena itu, kemungkinan sumber mineral ini berasal dari batulempung Formasi Kerek yang memang terdapat di sekitar Jatingaleh, Semarang. Berdasarkan hasil analisis mineral berat pada bagian hilir, mineral-mineral yang memiliki frekuensi tertinggi sampai terendah secara berurutan adalah ilmenit, magnetit, silimanit, muskovit, zirkon, andalusit, garnet, dan turmalin (Tabel 4 dan Gambar 6). Berdasarkan klasifikasi Mc
Lane seperti pada Tabel 2, maka diinterpretasikan bahwa provenance mineral berat pada bagian hilir adalah metamorfisme dinamotermal. Provenance ini sama dengan pada bagian hulu dan tengah Sungai Kaligarang. Hanya saja perbedaan terdapat pada komposisi mineral berat terbesar. Jika pada bagian hulu dan tengah didominasi magnetit, maka pada bagian hilir didominasi mineral ilmenit.

Berdasarkan asosiasi mineral berat dan provenans-nya dalam klasifikasi Mc Lane (llegieuno dkk., 2020; Nádaskay dkk., 2019) maka provenance dari material lepas yang ada di lokasi pengamatan ini adalah dynamothermal metamorphic. Dari 
provenance tersebut, maka dapat diketahui tempat batuan asalnya yaitu dimana terdapat kondisi terjadinya metamorfisme tingkat tinggi yang biasanya berada pada kulit bumi bagian dalam dan faktor yang berpengaruh adalah temperatur dan tekanan yang sangat tinggi. Secara geografis dan genetik penyebaran batuan metamorf dynamothermal ini sangat erat kaitannya dengan aktifitas orogenesa atau proses pembentukan pegunungan lipatan, dan meliputi daerah yang luas. Mekanisme terjadinya metamorfik dinamotermal pada Sungai Kaligarang dimulai sejak Zaman Tersier Awal. Pada mulanya terjadi intrusi basal dan andesit yang kemudian disusul adanya pengangkatan dan proses erosional. Bukti adanya pengangkatan adalah tersingkapnya Formasi Kerek dan Kalibeng yang terendapkan di laut dalam (Praptisih, 2016; Purasongka dkk., 2015). Selain itu Formasi Damar yang diinterpretasikan terendapkan pada zona transisi hingga batial juga tersingkap di permukaan (Syahbana dkk., 2020). Pada Kala Pliosen-Pleistosen terjadi reaktivasi sesar yang telah terbentuk pada Zaman Tersier Awal. Implikasi dari adanya reaktivasi sesar ini adalah terbentuknya sesar geser yang berarah timurlaut - baratdaya. Bahkan adanya reaktivasi ini terbentuk jalur sesar Kaligarang yang berarah utara - selatan akibat kompresi utara selatan sesuai dengan pola struktur jawa (Gambar 1). Jalur sesar Kaligarang yang pergerakannya dari Zaman Tersier Awal hingga Kuarter diinterpretasikan sebagai sumber panas dan tekanan yang tinggi pada metamorfisme dinamotermal. Peristiwa pengangkatan dan pergerakan sesar Kaligarang yang telah berlangsung sejak Zaman Tersier Awal-Kuarter merupakan genesa keberadaan asosiasi mineral berat yang ditemukan saat ini dari bagian hulu hingga hilir Sungai Kaligarang.

Pada ketiga lokasi pengamatan, mineral berat yang paling banyak ditemukan adalah ilmenit, magnetit, dan silimanit. Dari mineral-mineral tersebut dapat diketahui provenans-nya yaitu batuan mengalami metamorfisme dinamotermal berdasarkan klasifikasi Mc Lane (Ilegieuno dkk., 2020; Nádaskay dkk., 2019) dan juga batuan beku basa yang termetamorfkan secara tinggi sesuai dengan teori Pettijohn (Fossum dkk., 2020; Velasquez, 2019). Asosiasi mineral berat pada lokasi pengamatan di bagian hilir, hulu, dan tengah

Tabel 4. Data mineral berat di hilir menunjukkan bahwa persentase mineral terbanyak adalah ilmenit

\begin{tabular}{|c|c|c|c|c|c|c|}
\hline \multirow{2}{*}{ No } & \multirow{2}{*}{ Nama Mineral } & \multirow{2}{*}{ Frekuensi } & \multirow{2}{*}{ Presentase } & \multirow{2}{*}{$\begin{array}{c}\text { Simpangan } \\
\text { Baku }\end{array}$} & \multicolumn{2}{|c|}{ nilai terkoreksi } \\
\hline & & & & & + & - \\
\hline 1 & Magnetit & 87 & 27,79 & 5 & 32,79 & 22,79 \\
\hline 2 & Muskovit & 25 & 7,98 & 2 & 9,98 & 5,98 \\
\hline 3 & Andalusit & 19 & 6,07 & 2 & 8,07 & 4,07 \\
\hline 4 & Ilmenit & 114 & 36,42 & 6 & 42,42 & 30,42 \\
\hline 5 & Garnet & 8 & 2,55 & 1 & 3,55 & 1,55 \\
\hline 6 & Zircon & 22 & 7,02 & 2 & 9,02 & 5,02 \\
\hline 7 & Silimanit & 33 & 10,54 & 3 & 13,54 & 7,54 \\
\hline \multirow[t]{2}{*}{8} & Tourmaline & 5 & 1,59 & 1 & 2,59 & 0,59 \\
\hline & Jumlah & 313 & 100 & & & \\
\hline
\end{tabular}

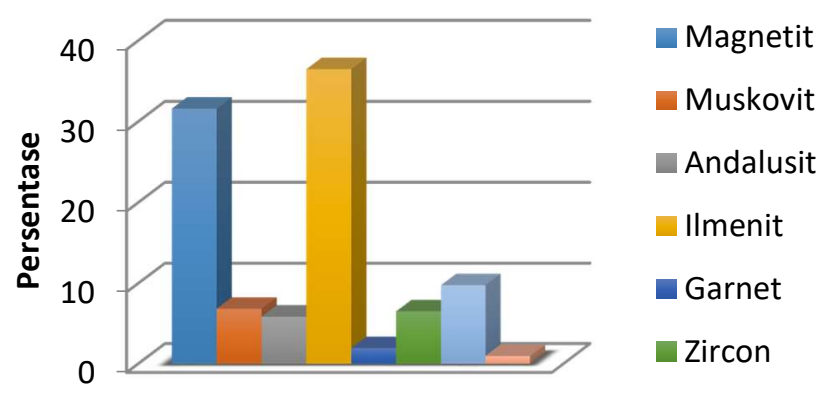

Gambar 6. Histogram nilai sebenarnya jumlah mineral berat di hilir Sungai Kaligarang didominasi ilmenit 
memiliki kesamaan. Berdasarkan provenance yang hampir sama pada ketiga bagian sungai yang berbeda tersebut (hilir, tengah, dan hulu), maka dapat diprediksi bahwa material yang ditransportasikan dari hulu, tengah dan kemudian hilir masih sama karena masih dalam satu sungai dan satu sumber hulu/satu aliran juga. Mineral berat merupakan indikator utama untuk mengetahui proses yang terjadi sampai asal-usul pembentukan batuannya yakni berasal dari batuan yang telah ada atau terbentuk terlebih dahulu baik batuan beku, metamorf maupun batuan sedimen yang lain yang mengalami pelapukan dan erosi yang kemudian diendapkan di tempat lain.

Resistensi mineral penyusun sangat mempengaruhi sampai mana mineral tersebut akan bertahan. Dari hal tersebut dapat dibuat suatu konsep bahwa mineral yang memiliki frekuensi tinggi adalah mineral-mineral yang memiliki resistensi tinggi terhadap proses abrasi atau pengikisan dan proses geologi lain yang terjadi. Dan semakin kecil frekuensi mineral tersebut akan semakin rendah resistensinya. Berdasarkan komposisi mineral yang didapatkan dan hasil analisis mineral beratnya yang kemudian dikaitkan dengan provenance-nya, maka dapat dipastikan bahwa antar jarak transport dan lokasi provenance-nya cukup jauh, karena mineral yang ditemukan yaitu berupa mineral metastabil. Bukti bahwa mineral tersebut telah mengalami transportasi jauh dari lokasi asalnya adalah adanya penurunan persentase mineral non-stabil seperti olivin yang pada bagian hulu mencapai $4,58 \%$ tetapi pada bagian tengah Sungai Kaligarang hanya 0,33\% dan di hilir Sungai Kaligarang tidak ditemukan mineral olivin.

\section{PENUTUP}

\section{Simpulan dan Saran}

Mineral berat yang paling banyak ditemukan di bagian hulu, tengah, dan hilir Sungai Kaligarang adalah ilmenit, magnetit, dan silimanit. Hal ini menandakan bahwa provenance sedimen Sungai Kaligarang adalah dynamothermal metamorphic yang merupakan metamorfisme tingkat tinggi. Provenance ini terkait dengan orogenesa atau pembentukan pegunungan lipatan yang terjadi pada wilayah yang luas. Provenance ini juga dapat dikaitkan dengan adanya pengangkatan dan pergerakan sesar aktif Kaligarang sejak Zaman Tersier Awal hingga Kuarter yang menyebabkan tekanan kompresi dan suhu tinggi sehingga terjadi metamorfisme skala regional yang menghasilkan mineral berat eksisting di Sungai Kaligarang.

Hasil penelitian ini dapat dikembangkan untuk mengetahui sejarah geologi Semarang secara lebih komprehensif terutama mekanisme sedimentasi yang dikaitkan dengan struktur sesar aktif. Provenance yang menunjukkan kesamaan antara bagian hulu, tengah, dan hilir dapat digunakan untuk melakukan korelasi antar lapisan batuan di Sungai Kaligarang.

\section{Ucapan Terima Kasih}

Ucapan terima kasih disampaikan kepada LPPM UNSOED yang telah memberikan hibah penelitian sehingga kajian mengenai provenance sedimen di Sungai Kaligarang dapat terlaksana dan selesai tepat waktu.

\section{DAFTAR PUSTAKA}

Agista, Z., Rachwibowo, P. dan Aribowo, Y. (2014), "Analisis Litologi Dan Struktur Geologi Berdasarkan Citra Landsat Pada Area Prospek Panasbumi Gunung Telomoyo Dan Sekitarnya, Kabupaten Magelang, Provinsi Jawa Tengah", Geological Engineering EJournal, Vol.6, No.1, hal. 278-293.

Azeriansyah, R., Prasetyo, Y. dan Yuwono, B.D. (2017), "Analisis Identifikasi Dampak Bencana Tanah Longsor dengan Menggunakan Unmanned Aerial Vehicle (UAV) (Studi Kasus: Kelurahan Ngesrep, Kecamatan Banyumanik)", Jurnal Geodesi Undip, Vol.6, No.4, hal. 474-484.

Fahrudin, F., Sadisun, I. dan Harsolumakso, A. (2011), Studi Sesar Aktif, Kinematik, dan Dinamik Zona Sesar Kaligarang (KGFZ) di Semarang, Makassar, Diambil dari http://eprints.undip.ac.id/36090/.

Fathullah, A., Awaluddin, M. dan Haniah, H. (2015), "Pengamatan Deformasi Sesar Kaligarang dengan GPS Tahun 2015", Jurnal Geodesi Undip, Vol.4, No.4, hal. 277-286.

Fauzih, R.A., Najib, N. dan Santi, N. (2019), "Analisis Daya Dukung Bored Pile pada Pembangunan Pondasi Jembatan Kali Kenteng dan Kali Serang Segmen Susukan di Ruas Jalan Tol Salatiga-Kartasura, PT. 
Waskita Karya (Persero), Kabupaten Semarang, Provinsi Jawa Tengah", Jurnal Geosains dan Teknologi, Vol.2, No.2, hal. 87-97. http://doi.org/10.14710/jgt.2.2.2019.87-97.

Fossum, K., Dypvik, H. dan Morton, A. (2020), "Provenance Studies of Southern Tanzania River Sediments: Heavy Mineral Signatures and U-Pb Zircon Ages", Journal of African Earth Sciences, Vol.170, hal. 103900.

http://doi.org/10.1016/j.jafrearsci.2020.103900.

Ghinassi, M., Moody, J. dan Martin, D. (2019), "Influence of Extreme and Annual Floods on Point-Bar Sedimentation: Inferences from Powder River, Montana, USA", GSA Bulletin, Vol.131, No.1-2, hal. 71-83. http://doi.org/10.1130/B31990.1.

Hidayat, E., Raharjo, P.D. dan Hartono, T. (2011), "Identifikasi Sesar Aktif di Sepanjang Kali Garang, Semarang Berdasarkan Data Geologi Permukaan", Prosiding Pemaparan Hasil Penelitian Puslit Geoteknologi-LIPI, hal. 149-154, http://doi.org/10.33332/jgsm.geologi.v23i1.97.

Ilegieuno, O.A., Ighodaro, E.J. dan Sunny, R.O. (2020), "Sedimentologic, Heavy Mineral and Provenance Studies of the Cretaceous Sediments in the Auchi Area of the Anambra Basin", Journal of Applied Sciences and Environmental Management, Vol.24, No.6, hal. 955-959. http://doi.org/10.4314/jasem.v24i6.1.

Jurnaliah, L., Muhamadsyah, F. dan Barkah, M.N. (2016), "Lingkungan Pengendapan Formasi Kalibeng Pada Kala Miosen Akhir di Kabupaten Demak dan Kabupaten Semarang, Jawa Tengah Berdasarkan Rasio Foraminifera Plangtonik dan Bentonik (Rasio P/B)", Bulletin of Scientific Contribution: GEOLOGY, Vol.14, No.3, hal. 233-238. http://doi.org/10.24198/bsc.

Kusuma, B.D.I., Awaluddin, M. dan Yuwono, B.D. (2017), "Survey Deformasi Sesar Kaligarang dengan Metode Pengamatan GPS Tahun 2016", Jurnal Geodesi Undip, Vol.6, No.1, hal. 93-99.

Laksono, F.A.T., Ramadhan, G., Nurmajid, R.W., Paramita, L.A.G. dan Tsai, L.L.-Y. (2020), "Analisis Zona Resapan Dan Keluaran Air Tanah Di Desa Kutayu, Kabupaten Brebes", Dinamika Rekayasa, Vol.16, No.2, hal. 97104. http://doi.org/10.20884/1.dr.2020.16.2.321.

Lestari, A.F., Widayati, N.T., Rusman, R., Supriyadi, S. dan Khumaedi, K. (2020), "Analisis Gaya Berat Di Trangkil Gunungpati Semarang", Jurnal Sains dan Edukasi Sains, Vol.3, No.2, hal. 53-57. http://doi.org/10.24246/juses.v3i2p53-57.

Mispaki, S.W., Prasetyo, Y. dan Awaluddin, M. (2015), "Analisis Deformasi Sesar Kaligarang Menggunakan
Metode Dinsar dan Geomorfologi Tahun 2007-2008", Jurnal Geodesi Undip, Vol.4, No.4, hal. 221-230.

Nádaskay, R., Žák, J., Sláma, J., Sidorinova, T. dan Valečka, J. (2019), "Deciphering the Late Paleozoic to Mesozoic tectonosedimentary evolution of the northern Bohemian Massif from detrital zircon geochronology and heavy mineral provenance", International Journal of Earth Sciences, Vol.108, hal. 2653-2681. http://doi.org/10.1007/s00531-019-01781-z.

Nurhandoko, B.E., Triyoso, K., Hadi, M.R.A., Rizal, I., Widarto, D.S. dan Nurhasan, N. (2020), "Karakterisasi Akuifer Berumur Miosen di Daerah Geologi Kompleks Thrust Fault Zona Kendeng dengan Rock Physics dan Tomografi Resistivitas", Jurnal Geofisika, Vol.18, No.2, hal. 53. http://doi.org/10.36435/jgf.v18i2.433.

Poedjoprajitno, S., Wahyudiono, J. dan Cita, A. (2008), "Reaktivitas Sesar Kaligarang, Semarang", Indonesian Journal on Geoscience, Vol.3. http://doi.org/10.17014/ijog.3.3.129-138.

Praptisih, P. (2016), "Karakteristik Batuan Induk Hidrokarbon Dan Hubungannya Dengan Rembesan Minyak Di Lapangan Minyak Cipluk, Kabupaten Kendal, Provinsi Jawa Tengah", Buletin Sumber Daya Geologi, Vol.11, No.2, hal. 133-134. http://doi.org/10.47599/bsdg.v11i2.26.

Purasongka, N.W., Syafri, I. dan Jurnaliah, L. (2015), "Karakteristik Batuan Sedimen Berdasarkan Analisis Petrografi pada Formasi Kalibeng Anggota Banyak", Bulletin of Scientific Contribution: GEOLOGY, Vol.13, No.1. http://doi.org/10.24198/bsc.

Raharjo, P. dan Yosi, M. (2017), "The Identification of Land Subsidance by Levelling Measurement and GPR Data at Tanjung Emas Harbour, Semarang", BULLETIN OF THE MARINE GEOLOGY, Vol.32, No.1. http://doi.org/10.32693/bomg.32.1.2017.351.

Rahayu, D.A., Harmoko, U., Yulianto, T., Widada, S. dan Dewantoro, Y. (2016), "Interpretasi Geologi Bawah Permukaan Daerah Potensi Mata Air Panas Kaliulo Kabupaten Semarang Berdasarkan Data Geomagnet Menggunakan Model 2-D \& 3-D", Youngster Physics Journal, Vol.5, No.4, hal. 291-302.

Rohendi, R. dan Aryanto, N.C.D. (2016), "Seafloor Sediment Characteristics and Heavy Mineral Occurences at Betumpak Cape and Adjacent Area, Bangka Strait, Bangka Belitung Province", BULLETIN OF THE MARINE GEOLOGY, Vol.27, No.1, hal. 7-18. http://doi.org/10.32693/bomg.27.1.2012.41.

Santoso, B. (2016), "Penerapan Metode Geolistrik 2D Untuk Identifikasi Amblasan Tanah Dan Longsoran Di Jalan Tol Semarang - Solo Km 5+400 Km 5+800", 
Spektra: Jurnal Fisika dan Aplikasinya, Vol.1, No.2, hal. 179-186. http://doi.org/10.21009/SPEKTRA.012.13.

Setyanto, A. dan Surachman, M. (2017), "The Occurences of Heavy Mineral Placer at Kendawangan and Its Surrounding, West Kalimantan Province", Bulletin of the Marine Geology, Vol.32, No.1, hal. 33-40.

Supriyadi, S., Khumaedi, K., Setiawan, F. dan Mm, T. (2020), "Pemodelan 2D Lapisan Bawah Permukaan Berdasarkan Data Gaya Berat Mikro", Jurnal Penelitian Saintek, Vol.25, No.1, hal. 44-52. http://doi.org/10.21831/jps.v25i1.28566.

Syahbana, A., Goro, G., Saputra, O., Aditramulyadi, D., Irsyam, M., Asrurifak, M. dan Djazilus, H. (2020), Application of Modified PSHA USGS Software in Java Island Bed Rock Peak Ground Acceleration and Hazard Curve with 2475 Years Return Period, Vol.29, hal. 3138-3148.

Velasquez, F. (2019), "Characterization of heavy minerals from active sediments of the Magdalena River basin, Colombia: implications in the provenance analysis of the fluvial record", Boletin de Geologia, Vol.41, hal. 137-147. 